\title{
SDHB Gene
}

National Cancer Institute

\section{Source}

National Cancer Institute. SDHB Gene. NCI Thesaurus. Code C97773.

This gene plays a role in electron transport in the mitochondria. 